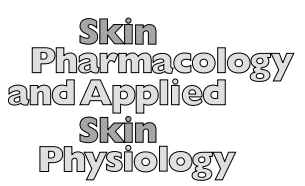

Afaq, F. 297

Ambach, A. 307

Bernhardt, J. 307

Biesalski, H.-K. 307

Billiar, T. 348

Chaudhuri, R.K. 373

Denfeld, R.W. 330

Eberle, J. 321

Elsner, P. 367

Fecker, L.F. 321

Fischer, T.W. 367

Fuchs, J. 379

Geilen, C.C. 321

Gollnick, H.P.M. 307, 360

Greul, A.-K. 307
Groth, N. 379

Gruijl, F.R. de. 316

Grundmann, J.-U. 307

Hara, H. 330

Heinrich, F. 307

Herrling, T. 379

Hertting, T. 353

Hipler, U.-C. 367

Hossini, A.M. 321

Knöll, B. 367

Kulms, D. 342

Martin, S. 330

Mukhtar, H. 297

Orfanos, C.E. 281, 321, 353

Packer, L. 282
Pfitzner, I. 307

Sánchez Ruderisch, H. 335, 353

Scholz, G. 367

Schwarz, C. 335,353

Schwarz, T. 342

Shang, J. 321, 335, 353

Siebenwirth, C. 360

Sies, H. 291

Simon, J.C. 330

Stahl, W. 291

Tebbe, B. 281, 321, 335, 353

Valacchi, G. 282

Vodovotz, Y. 348

Weller, R. 348

Zastrow, L. 379

\title{
Subject Index Vol. 15, No. 5, 2002
}

Antioxidant(s) 282, 307, 360, 367, 373

-, photooxidation 291

Apoptosis 321, 342, 348

$L$-Ascorbic acid 353

$\beta$-Carotene 360

Carotenoids 291

Cell culture 291

Death receptor activation 342

Dendritic cell 330

DNA damage 342

Electron spin resonance spectroscopy 379

Erythema 291

Free radicals 379

HaCaT 335

Heat stress proteins 282

Hydrolyzable tannins 373

Immune regulation 330
Keratinocyte(s) 348, 353

Leukocytes 367

Lipid peroxidation 282

Melanocytes 321, 353

Melanoma 321

Mucosa cells 360

Natural product 373

Nitric oxide 348

Nuclear factor- $\kappa \mathrm{B} 321,335,353$

Oxidative stress 291, 373

Peroxynitrite 348

Phyllanthus emblica 373

Pigmentation 321

Plasma 307

Pro-oxidant 373

Protection 291

Reactive oxygen species 316,342 , 367

Regulatory T cell 330
Signaling pathways 316

Skin 282, 307

- cancer 316

- care 373

- types 360

Sunburn 291

Superoxide 348

T cell 330

Transition metals 373

Trioxsalen 335

Ultraviolet radiation 316,342 , 348

UV light 291, 307, 360, 367

UVA 335,353

- irradiation 379

UVB irrradiation 330

Vitamin E 282

\section{KARGER}

(c) 2002 S. Karger AG, Basel

Fax + 41613061234

E-Mail karger@karger.ch

www. karger.com

Accessible online at:

www. karger.com/journals/sph 